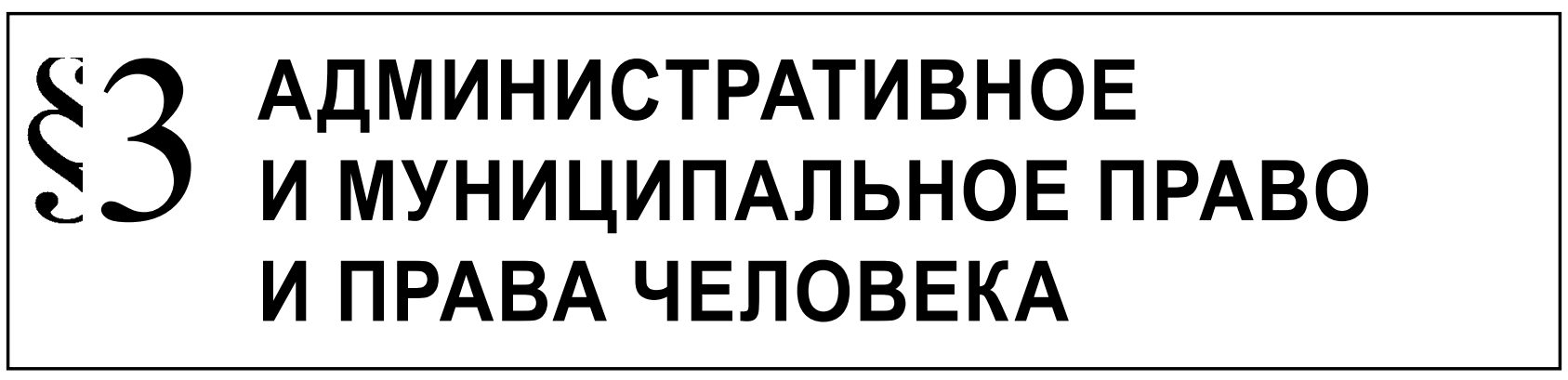

Адмиралова И.А.

\title{
СТАТУС ГРАЖДАН КАК СУБЪЕКТОВ АДМИНИСТРАТИВНОГО ПРАВА И РОЛЬ ПОЛИЦИИ В ЕГО ОБЕСПЕЧЕНИИ
}

\begin{abstract}
Аннотация: в статье рассматриваются правовые и организационные проблемы реализации административно-правового положения граждан, раскрывается содержание административной правосубъектности гражданина, а также показывается роль полиции в механизме обеспечения прав и законных интересов граждан в сфере управления. На основании проведенного исследования формулируются предложения по совершенствованию административного законодательства, регламентирующего статус граждан и деятельность сотрудников полиции. В статье также отмечается, что в работе полиции первостепенное значение принадлежит обеспечению прав и законных интересов граждан. етодологическую основ статьи составили современные достижения теории познания. В процессе исследования применялись теоретический, общефилософские методы (диалектика, системный метод, анализ, синтез, аналогия, дедукция, наблюдение, моделирование), традиционно правовые методы (формально-логический), а также методы, используемые в конкретно-социологических исследованиях (статистические, экспертные оценки и др.). Проблема прав и свобод граждан одна из центральных в юридической науке. Этому вопросу посвящено много научных трудов самого различного характера. Однако, логика развития общественных процессов, а также прак-тика государственного строительства, обусловливает объективную необхо-димость обратиться еще раз к проблеме правового положения граждан в срере действия норм административного права. Иными словами, в настоящее время весьма актуален вопрос раскрытия правового статуса гражданина в режиме административно-правовой действительности, кроме того, первосте-пенной задачей представляется необходимость определение роли и значения российской полиции $в$ обеспечении прав, свобод граждан в самых различных срерах государственного управления.
\end{abstract}

Ключевые слова: человек, гражданин, личность, поличия, статус, гарантии, контроль, защита, охрана, положение.

$\Pi$ роблема прав и свобод граждан одна из центральных в юридической науке. Этому вопросу посвящено много научных трудов самого различного характера ${ }^{1}$. Однако, логика раз-

\footnotetext{
1 См.: Арзамасов Ю.Г. Нормотворческая деятельность МВД России в механизме реализации прав человека и гражданина. - М., 2000; Воеводин Л.Д. Юридический статус личности в России. - М., 1997; Витрук Н.В. Общая теория правового положения личности. - М., 2008; Гасанов К.К. Основные права человека: вопросы неотчуждаемости. - М., 2003; Пчелинцев С. В. Проблемы ограничения права и свобод граждан в условиях особых правовых режимов. - М., 2006; Права человека и политическое реформирование / Под ред. Е.А. Лукашевой. - М., 1997; Ростовщиков И.В. Обеспечение и защита прав и свобод личности: вопросы теории и практика
}

вития общественных процессов, а также практика государственного строительства, обусловливает объективную необходимость обратиться еще раз к проблеме правового положения граждан в сфере действия норм административного права. Иными словами, в настоящее время весьма актуален вопрос раскрытия правового статуса гражданина в режиме административно-правовой действительности, кроме того, первостепенной задачей представляется необходимость определение роли

органов внутренних дел: Автореф. дис. ... д-ра юрид. наук. М., 1997; Малько А.В., Субочев В.В., Шериев А.М. Права, свободы и законные интересы: проблемы юридического обеспечения. - М., 2010 и др. 
и значения российской полиции в обеспечении прав, свобод граждан в самых различных сферах государственного управления. Вполне понятно, что статус гражданина - эта категория весьма сложная и собирательная, поскольку гражданин, как субъект права, может участвовать в самых различных правоотношениях и, тем самым, реализовывать предоставленные ему конституционные, гражданские, а также иные субъективные права в самых различных сферах. В зависимости от того, какое право гражданин реализует и определяется его правовое состояние в данный момент, иными словами зависит его правовой статус.

Исходным правовым статусом гражданина является его конституционно-правовой статус. Такой подход во многом определяется тем, что Конституция России закрепляет положение о том, что человек, его права и свободы являются высшей ценностью. Признание, соблюдение и защита прав и свобод человека и гражданина - обязанность государства (ст.2). В Российской Федерации признаются и гарантируются права и свободы человека и гражданина согласно общепризнанным принципам и нормам международного права и в соответствии с настоящей Конституцией. Основные права и свободы человека неотчуждаемы и принадлежат каждому от рождения. Осуществление прав и свобод человека и гражданина не должно нарушать права и свободы других лиц (ст. 17). Также Конституция определяет, что права и свободы человека и гражданина являются непосредственно действующими. Они определяют смысл, содержание и применение законов, деятельность законодательной и исполнительной власти, местного самоуправления и обеспечиваются правосудием (ст. 18).

Эти и ряд иных предписаний Конституции Российской Федерации, которые касаются непосредственно гражданина, определяют содержание различных его правовых статусов, которые приобретает или получает гражданин, вступая в те или иные правоотношения. Как отмечает Н.Ю. Хаманева, «...правовой статус гражданина - одна из важнейших политико-правовых категорий, неразрывно связанных с социальной структурой общества, уровнем демократии и состоянием законности в нем. Юридический статус человека и гражданина в обществе, государстве представляет собой сложный и многосторонний конституционно-правовой механизм»².

\footnotetext{
2 См.: Хаманева Н.Ю. Понятие и сущность административно-правового статуса гражданина // Административноправовой статус гражданина. - М., 2004. - С. 3.
}

Нужно отметить, что конституционные предписания относительно правового статуса личности во многом предопределены нормами международного права. В частности, по этому вопросу начиная с середины XX в. принят целый ряд нормативных документов: Всеобщая декларация прав человека (1948), Конвенция о защите прав человека и основных свобод (1950), Международный пакт о гражданских и политических правах (1966), Международный пакт об экономических, социальных культурных правах (1966) и др.

Эти акты важны для развития российского законодательства вообще и административного законодательства, в частности, поскольку они содержат универсальные категории правового статуса личности. Оценивая значение норм международного права, А.П. Шергин в свое время подчеркнул, что закрепление международно-правовых стандартов прав человека в российском законодательстве является важной предпосылкой их реализации. Однако само по себе признание международно-правовых стандартов прав человека недостаточно для реального воплощения их в жизнь ${ }^{3}$.

Говоря о конституционно-правовом статусе гражданина или о его конституционных правах, можно сделать вывод о том, что несмотря на прямое действие Конституции, а также ее высшую юридическую силу, целый ряд ее положений не может быть реализован гражданином без специальной законодательной регламентации. Так, право гражданина на обращение, право на свободу передвижения, право на поступление на государственную службу, право на проведение мирных публичных мероприятий и др., не могут быть реализованы напрямую гражданином без взаимодействия с органами исполнительной власти. Эти и некоторые другие права, которые предоставлены гражданину исходя из их содержания, а также публичного проявления, не могут быть реализованы без применения, исполнения или использования норм административного права. В этой связи верен тезис о том, что административно-правовой статус граждан является частью их общего правового положения. Его содержание определяется тем местом, которое занимают граждане в политической, социально-культурной жизни страны, в сфере управления и состоит из совокупности разнообразных связей и отношений между обществом, государством и гражданином,

См.: Шергин А.П. Права человека и административная политика // Проблемы обеспечения прав человека в деятельности органов внутренних дел. - М., 1994. - С. 56. 
урегулированных нормами права. И.А. Иванова, верно подметила, что специфика административноправового статуса граждан в значительной степени определяется особенностями соответствующей управленческой сферы ${ }^{4}$.

Приведенный тезис в целом верен, сфера управленческой деятельности действительно достаточно, специфична. Эта специфика определяется тем, что в ней много отношений, которые носят властный характер, для поддержания ее содержания используются императивные методы воздействия на участников соответствующих отношений. Однако надо признать, что в настоящее время возможности управленческого воздействия, в частности, на граждан существенно снизились, вместе с тем, это не умаляет значение административно-правового регулирования, поэтому сейчас мы можем говорить об изменении форм и методов управленческого, а в некоторых случаях и полицейского воздействия. В этой связи вполне возможно дифференцировать такое воздействие собственно на управленческое (в узком значении этого слова) и полицейское воздействие. У каждого из видов административного воздействия на граждан своя цель, основания, а также правовые последствия и др. Такой подход существенно расширяет предмет административно-правового регулирования, делая его более дифференцированным, гибким, а также целенаправленным.

Как отмечал в свое время Н.И. Буденко, административное законодательство, регулирующее правовое положение граждан в сфере государственного управления, конкретизирует права и обязанности граждан, закрепленные в Конституции, устанавливает порядок их реализации, детализирует их гарантиями. В связи с этим, в нормах административного права конституционные положения получают свое развитие в правах и обязанностях, которые прямо не установлены Конституцией ${ }^{5}$. В продолжение этого можно также отметить, что конституционные права, по сути, представляют собой не условие, не способность к определенному социальному благу, а собственно это благо ${ }^{6}$.

4 См.: Иванова И.А. Административно-правовая охрана субъективных прав советских граждан в сфере общественного порядка: Дис. ... канд. юрид. наук. - М., 1986. - С. 26.

5 См.: Буденко Н.И. Административно-правовое положение граждан в сфере общественного порядка: Дис. ... канд. юрид. наук. - М., 1986. - С. 27.

6 См.: Иванова И.А. Административно-правовая охрана субъективных прав советских граждан в сфере общественного порядка: Дис. ... канд. юрид. наук. — М., 1986. - С. 26.
Закрепление конституционных прав граждан в административном законодательстве очень содержательно. Так, согласно Конституции России, граждане Российской Федерации имеют право обращаться лично, а также направлять индивидуальные и коллективные обращения в государственные органы и органы местного самоуправления (ст. 33).

Порядок работы с индивидуальными и коллективными предложениями, заявлениями и жалобами граждан и организаций регламентируется Федеральным законом от 2 мая 2006 г. «0 порядке рассмотрения обращений граждан Российской Федерации» ${ }^{7}$

В Министерстве внутренних дел порядок работы с обращениями граждан в настоящее время регламентируется Приказом МВД России от 12 сентября 2013 г. № 707 «Об утверждении инструкции об организации рассмотрения обращений граждан в системе Министерства внутренних дел Российской Федерации ${ }^{8}$, Приказом МВД России от 17 октября 2013 г. № 850 «Об утверждении регламента Министерства внутренних дел Российской Федерации»" а также иными нормативными правовыми актами Российской Федерации и МВД России. Эффективность реализации целого ряда конституционных прав и свобод граждан зависит от качества административного законодательства. Как верно отметил С. Д. Князев «...административно-правовой статус граждан в значительной мере зависит от состояния законодательства, закрепляющего их права и обязанности в сфере управления» ${ }^{10}$.

Таким образом, нормами административного права, которые содержатся в вышеперечисленных приказах МВД, определяется порядок реализации обозначенного конституционного права. Данный порядок включает такие этапы как: прием и первичную обработку обращений; регистрацию и учет обращений; принятие организационных решений о порядке рассмотрения обращений; рассмотрение обращений по существу и принятие по ним решений; подготовку и направление ответов на обращения; хранение обращений и материалов по их рассмотрению; личный прием граждан; анализ

\footnotetext{
Собрание законодательства РФ. - 2006. - № 19. - Ст. 2060.

8 Российская газета. - 2014. - 17 января.

9 Российская газета. - 2013. - 21 ноября.

10 См.: Князев С. Д. Некоторые вопросы законодательного обеспечения административно-правового статуса российских граждан // Административно-правовой статус гражданина. - М., 2004. - С. 13.
} 
рассмотрения обращений; контроль за рассмотрением обращений.

Также необходимо отметить, что многие вопросы, связанные с защитой прав личности напрямую регламентируются нормами административного права. Как отмечает Н.Г. Салищева «... проблема защиты прав и свобод человека и гражданина в сфере исполнительной власти неразрывно связана с административно-правовым статусом гражданина как субъекта многообразных административных правоотношений» ${ }^{11}$.

В этой связи административно-правовой статус гражданина имеет весьма существенное значение в содержание правового положения личности. Поэтому вполне очевидно, что административноправовое положение гражданина имеет принципиальное значение для его самореализации, а также для выстраивания им нормальных взаимоотношений с органами государственной власти и их должностными лицами, в частности, это необходимо при предоставлении гражданину тех или иных государственных услуг. Административно-правовой статус также представляется весьма важным, например, при легитимной защите гражданином своих личных (субъективных) прав от мер административного воздействия (принуждения), которые порой могут исходить от должностных лиц исполнительной власти или иных органов власти и управления и др.

Легитимные формы защиты гражданина могут состоять в его возможности действовать в состоянии крайней необходимости, и это позволяет ему избежать мер юридической ответственности. Вполне очевиден тезис о том, что гражданин не может быть привлечен к ответственности, если он действовал по отношению к представителю власти в режиме крайней необходимости. Как следует из КоАП России, не является административным правонарушением причинение лицом вреда, охраняемым законом интересам в состоянии крайней необходимости, то есть для устранения опасности, непосредственно угрожающей личности и правам данного лица или других лиц, а также охраняемым законом интересам общества или государства, если эта опасность не могла быть устранена иными средствами и если причиненный вред является менее значительным, чем предотвращенный вред (ст. 2.7).

11 См.: Салищева Н.Г. Механизм защиты прав граждан в сфере исполнительной власти / В книге «Общая теория прав человека» / Отв ред. Е.А. Лукашева. - М., 1996. - С. 278.
Иногда имеют место трудности в определении критериев правомерности действий гражданина в состоянии крайней необходимости, в этой связи необходимы более четкие критерии определения границ правомерности соответствующего поведения. Как отмечал в свое время И.Ш. Килясханов «... для преодоления подобных трудностей важно разработать критерии оценки ущерба, с последующим их законодательным закреплением» ${ }^{12}$.

Таким образом, статус гражданина - это его правовое состояние в той или иной сфере жизнедеятельности, содержательное наполнение этого правового состояния, как уже частично отмечалось, зависит от конкретной ситуации, в которую он попал. В этой связи в содержательном плане правовой статус гражданина в сфере действия норм административного права определяется такими составляющими, как права, обязанности, гарантии реализации права и исполнения обязанностей, а также ответственность за неисполнение возложенных на гражданина обязанностей или нарушение им установленных правовых запретов. Это классический набор элементов административно-правового статуса гражданина. В этой связи правильно отмечает Н.И. Побежимова, что «...права, свободы и обязанности гражданина опосредуют его связи между обществом и личностью, органами исполнительной власти и гражданином» ${ }^{13}$. В науке существует точка зрения, согласно которой права и обязанности личности не какая-то абстракция, а собственно и есть само право. Как раз об этом писал Г.В. Мальцев «... права и обязанности не находятся где-то около или рядом с системой права, они сами есть право, являются основным исходным его элементом. Ничего более важного в структуре права по существу нет. Система прав и обязанностей - сердцевина, центр правовой сферы, и здесь лежит ключ к решению основных юридических проблем» ${ }^{14}$.

Из приведенной цитаты видно, какое большое значение имеют права и обязанности в российском

12 См.: Килясханов И.Ш. Права и свободы граждан в сфере административной деятельности милиции // Специфика правового регулирования в период становления рыночных социально-экономических отношений. - Омск,1996. C. 44 .

13 См.: Побежимова Н.И. Обеспечение прав и свобод гражданина (административно-правовой аспект) // Проблемы обеспечения прав человека в деятельности органов внутренних дел. - М., 1994. - С. 67.

14 См.: Мальцев Г.В. Права личности: юридическая норма и социальная действительность // Конституция СССР и правовое положение личности. - М., 1979. - С. 48. 
праве, это еще раз подтверждает тезис о том, что обеспечение правового статуса личности - одна из главнейших обязанностей в деятельности органов государственной власти в целом и полиции в частности.

Существует точка зрения относительно содержания правового статуса личности, указывающая на то, что его составной частью является гражданство. Такая позиция, по всей видимости, обусловлена тем, что гражданство является основанием для наделения человека полным объемом прав и возложение на него всего комплекса обязанностей, в частности в сфере административно-правовой действительности. Как известно, гражданство - это особая правовая связь человека с государством, которая выражается в совокупности взаимных прав и обязанностей. Отсутствие у лица гражданства страны пребывания (проживания), безусловно, снижает его правосубъективность, иными словами ограничивает его правовые возможности, а в некоторых случаях влечет возложение на него дополнительных обязанностей. В этой связи, полным объемом прав и обязанностей в административно-правовой сфере могут обладать только граждане Российской Федерации. Но это вовсе не означает, что иностранные граждане и лица без гражданства лишены возможности реализовать свою правосубъектность на территории нашей страны. Законно находясь на территории нашей страны, эта категория лиц пользуется многими теми же правами, что и граждане России. Как следует из Конституции России, иностранные граждане и лица без гражданства пользуются в Российской Федерации правами и несут обязанности наравне с гражданами Российской Федерации, кроме случаев, установленных федеральным законом или международным договором Российской Федерации (ст. 62). В равной степени с гражданами России, иностранные граждане и лица без гражданства имеют право на полицейскую защиту.

Как следует из Федерального закона от 7 февраля 2011 г. «0 полиции» ${ }^{15}$, полиция предназначена для защиты жизни, здоровья, прав и свобод граждан Российской Федерации, иностранных граждан, лиц без гражданства, для противодействия преступности, охраны общественного порядка, собственности и для обеспечения общественной безопасности. Полиция незамедлительно приходит на помощь каждому, кто нуждается в ее защите от преступных и иных противоправных посягательств (ст. 1).

15 Собрание законодательства РФ. — 2011. — № 7. — Ст. 900.
В любой стране мира иностранцы имеют меньший объем прав по сравнению с гражданами соответствующего государства, на данную категорию лиц возлагаются и дополнительные обязанности, которые обусловлены режимом их пребывания. В свою очередь, за неисполнение требований режима пребывания к иностранным гражданам и лицам без гражданства может быть применено такое административное наказание, как их выдворение за пределы Российской Федерации. Полиция в пределах своей компетенции обеспечивает иммиграционный контроль в отношении данной категории лиц пребывающих на территории нашей страны.

Говоря о правовом положении гражданина в рассматриваемой сфере, нельзя не затронуть вопросов, касающихся административной правосубъектности, которая включает такие составляющие, как административная правоспособность, административная дееспособность и административная деликтоспособность. Далеко не каждый гражданин приобретает административную правосубъектовность сразу в полном объеме. Это состояние приобретается гражданином постепенно, с достижением определенного возраста, наступлением определенного срока, получением необходимого образования (подготовки), выполнения квалификационных требований и др. Правосубъектность гражданина в определенных случаях может быть ограничена федеральным законом в той мере, в какой это необходимо в целях защиты основ конституционного строя, нравственности, здоровья, прав и законных интересов других лиц, обеспечения обороны страны и безопасности государства.

Как уже отмечалось, права граждан, как субъектов административного права весьма разнообразны, поэтому их можно классифицировать по определенным критериям. Так, А.П. Коренев делил права граждан, как субъектов административного права по степени возможности их реализации на абсолютные и относительные, исходя из всеобщности реализации прав, подразделял их на общие и специальные ${ }^{16}$. А.П. Алехин, А.А. Кармолицкий, Ю.М. Козлов права и обязанности граждан в административном праве подразделяют на статутные и адекватные тем сферам, в которых они могут реализовываться ${ }^{17}$.

16 См.: Коренев А.П. Административное право. Ч І. - М., 2000. - C. 74 .

17 См.: Алехин А.П., Кармолицкий А.А., Козлов Ю.М. Административное право Российской Федерации. - М., 1997. C 103. 
Д.Н. Бахрах права граждан, как субъектов административного права подразделил на конкретизирующие, развивающие, обеспечивающие реализацию конституционных прав. А также права, регулируемые только нормами административного права, получившие свое первичное закрепление в источниках административного права. С точки зрения механизма реализации, автором также выделяются абсолютные и относительные права ${ }^{18}$. Н.И. Буденко, говоря уже исключительно об административных правах граждан в сфере общественного порядка, дифференцировал их на права граждан. как субъектов управления общественным порядком и права граждан. как объектов такого управления ${ }^{19}$.

В научной литературе существуют иные критерии классификации прав граждан, как субъектов административного права. В основу каждой из имеющихся классификаций положены в целом, примерно одинаковые критерии. На наш взгляд, права граждан в сфере административно-правовой действительности, могут быть подразделены в зависимости от того, какими нормами они закреплены, а именно - права материального и административно-процессуального характера, в зависимости от сферы их реализации права могут быть подразделены на права управленческого и полицейского характера.

В зависимости от «свободы» реализации соответствующие права, возможно подразделить на права, реализация которых допускается свободно и права, реализация, которых требует их согласования с органами государственной власти и управления. Права граждан в сфере административно-правовой действительности могут быть также подразделены в зависимости от правового механизма их реализации. В частности, права, порядок реализации которых определен нормами административного права, содержащиеся в федеральном законодательстве, права, реализация которых определяется актами федеральных органов исполнительной власти. Кроме того, можно выделить права, порядок реализации которых определен нормативными правовыми актами субъектов Российской Федерации, а также права, порядок реализации которых определен актами органов местного самоуправления.

18 См.: Бахрах Д.Н. Административное право России. - М., 2000. - С. 69.

19 См.: Буденко Н.И. Административно-правовое положение граждан в сфере общественного порядка: Дис. ... канд. юрид. наук. - М., 1986. - С. 27.
В диалектической связи с правами граждан, как субъектов административного права, находятся обязанности. В сфере административно-правовой действительности установлено достаточно много обязанностей и правовых запретов, которые адресованы как гражданам, так и хозяйствующим субъектам. В отличие от прав, которые закреплены в Конституции России и получивших свое развитие в административном законодательстве, сказать то же самое об обязанностях в полной мере нельзя. Конституция России закрепляет не так уж много обязанностей, адресованных гражданам, в частности, в Конституции прямо говориться об обязанности гражданина служить в Вооруженных Силах РФ, платить законно установленные налоги, бережно относиться к окружающей среде. Но есть и указание на одну общую, но очень принципиальную обязанность гражданина, а именно - соблюдать Конституцию и законы. Тем самым, гражданин обязан соблюдать целый ряд законодательных и иных нормативных правовых предписаний, которые действуют в публично-правовой сфере. В юридической литературе верно отмечается, что обязанности, которые возлагаются на граждан в сфере действия норм административного права - а это управленческая и полицейская сфера - носят абсолютный характер, исполнение обязанностей непреложно. Поэтому, у гражданина не должно быть сомнений в вопросе выполнять или не выполнять в полном объеме предписания норм административного права, соблюдать установленный в той или иной сфере административный запрет.

Государство устанавливает в отношении граждан только те обязанности, которые граждан им вполне в состоянии выполнить. Конечно, не стоит абсолютизировать реальную действительность порой в силу целого ряда обстоятельств как объективного, а по большей части и субъективного порядка гражданин не выполняет предписаний нормы административного права и, тем самым, совершает при этом административное правонарушение. Задача государства, в лице компетентных органов, в том числе и полиции, создать такие условия жизнедеятельности человека, чтобы он совершая как можно меньше правонарушений, по возможности максимально полно соблюдал самые различные административные запреты, ограничения, обязанности и т.д. Для этого необходимо совершенствовать управленческую и полицейскую деятельность, совершенствовать формы и методы охраны общественного порядка и обеспечения общественной безопасности, а также проводить 
большую работу в сфере благоустройства и профилактики различного рода правонарушений.

Для того, чтобы гражданин чувствовал себя полноценным субъектом административного права, необходимо создать для него возможность реализовать предоставленные ему права, а также обеспечить выполнение возложенных на него административных обязанностей, иными словами - необходимы соответствующие гарантии. Гарантии должны касаться как прав, так и обязанностей гражданина. Как верно отметила Н.И. Побежимова, «административно-правовой статус гражданина, представляет собой не только комплекс его прав и обязанностей, но также и их гарантий, установленных государством. В свою очередь, гарантии юридических прав и обязанностей гражданина включают как охрану граждан, так и условия и средства, которые обеспечивают их фактическую реализацию со стороны государства» ${ }^{20}$.

Вполне очевидно, что только обладание правами, а также возложение обязанностей на гражданина в сфере административно-правовой действительности, по сути ничего не дает. Необходим механизм реализации соответствующих прав и обязанностей, и от того, насколько он оптимален, учитывает сложные жизненные и управленческие ситуации, зависит эффективность функционирования органов государственной власти и управления, в том числе и работающих в сфере внутренних дел. Зачастую административно-правовой механизм реализации прав и исполнения обязанностей, возложенных на гражданина, должным образом материально-технически, информационно, а также кадрово не обеспечен. Все это создает ситуацию, при которой гражданин просто не может вовремя получить государственную услугу, состоящую, по сути, в получении банальной справки, выписки, свидетельства и т.п., тем самым, гражданин не может добросовестно исполнить обязанность, например такую, как уплата административного штрафа. Все это создают ситуацию недоверия к государственной власти и, прежде всего, власти исполнительной, провоцирует коррупцию. В этой связи, возможно, был прав И.Ш. Килясханов, говоря о том, что совершенствование механизма реализации административно-правового статуса гражданина должно осуществляться в направлении

20 См.: Побежимова Н.И. Обеспечение прав и свобод гражданина (административно-правовой аспект) // Проблемы обеспечения прав человека в деятельности органов внутренних дел. - М., 1994. - С. 67. развития элементов, обеспечивающих реализацию прав граждан в так называемом бесконтактном режиме. Речь идет о предоставлении гражданину возможности воспользоваться принадлежащим ему правом в случаях, когда должностное лицо не обеспечило принятие решения в установленном порядке и в установленные сроки ${ }^{21}$.

Исходя из вышеприведенных тезисов, можно заключить, что верно также и утверждение В.В. Полянского о том, что сущность административноправового статуса гражданина выявляется в процессе реализации прав и свобод и выражается в их гарантиях, которые материализуются в его взаимоотношениях с органами исполнительной власти ${ }^{22}$.

Н.Н. Волчанская, все гарантии прав человека объединила в государственные гарантии, под которыми понимает систему политических, организационных, специально-юридических средств (инструментов и технологий), которые непосредственно выражают назначение, компетенцию (правомочия и обязанности) и ответственность государства в сфере обеспечения защиты прав человека и осуществляются в правозащитной деятельности его органов и должностных лиц ${ }^{23}$.

С данной точкой зрения можно согласиться, поскольку ответственность государства за неисполнение или ненадлежащее исполнение своих обязанностей перед гражданином, весьма существенно нарушает его права.

В этой связи возможно закрепление в КоАП России целого ряда составов административных правонарушений, которые будут предусматривать административную ответственность органов государственной власти, которые выступают как юридические лица публичного права, за не исполнение своих обязанностей, а также нарушение прав граждан в различных сферах государственного и муниципального управления.

В этой связи вполне логично, что юридические гарантии занимают важное место в содержании

\footnotetext{
21 См.: Килясханов И.Ш. Конституционно-правовые основы административно-правового статуса гражданина и механизм его реализации // Актуальные вопросы административного и финансового права. - М., 2004. - С. 34.

22 См.: Полянский В.В. Исполнительная власть и гражданин: проблемы гарантирования административно-правового статуса гражданина // Административно-правовой статус гражданина. - М., 2004. - С. 18.

23 См.: Волчанская А.Н. Государственные гарантии защиты прав человека в России: теоретико-правовой аспект: Автреф. дис. ... канд. юрид наук. - Саратов. 2013. - С. 8.
} 
административно-правового статуса гражданина, эти гарантии достаточно формальны, имеют свою форму и процедуру реализации. Однако необходимо помнить, что добиться должного поведения со стороны гражданина исключительно с помощью правовых гарантий, а также иных административно-правовых средств, достаточно сложно. Как верно писал в свое время Н.В. Витрук «юридические гарантии прав и обязанностей личности не исчерпываются средствами борьбы с нарушением этих прав и обязанностей. Они включают закрепленные в праве средства, обеспечивающие реализацию прав и обязанностей личности» ${ }^{24}$.

За последние годы административное законодательство пополнилось значительным количеством самых различных запретительных и ограничительных предписаний, весьма серьезно ужесточены административные наказания и др. Однако ужесточение административной политики не повлекло за собой кардинальных изменений в деле укрепления правопорядка, а также повышения законности и дисциплины в российском обществе. Также не вырос и уровень правовой культуры граждан. Это еще раз говорит о том, что юридические гарантии прав и исполнения возложенных обязанностей должны находиться во взаимосвязи с экономическими, политическими, культурными, а также организационными гарантиями. Относительно последних необходимо сказать отдельно.

Является аксиомой тот факт, что надлежащим образом организованная управленческая и полицейская деятельность напрямую способна обеспечить правомерное поведение со стороны гражданина, когда тот например, максимально быстро и качественно получит необходимую ему государственную услугу, и соответственно быстро и без бюрократических проволочек исполнит возложенную на него фискальную или иную штрафную обязанность. В настоящее время, к сожалению, приходиться говорить о том, что государство зачастую само провоцирует гражданина нарушать правовые предписания вообще и административно-правовые предписания, в частности. Излишняя формализация процесса управления, слабая процессуальная регламентация порядка предоставления государственных услуг, а также запоздалые, а часто и непродуманные управленческие решения все это нивелирует положительную практику управленческой и полицейской работы, снижает

24 См.: Витрук Н.В. Основы теории правового положения личности в социалистическом обществе. - М., 1979. - С. 205. правоохранительный потенциал, в том числе и в деятельности полиции. В этой связи организационные гарантии в обеспечении статуса граждан как субъектов административного права имеют весьма существенное значение. Для обеспечения прав и свобод граждан создаются различные органы государственной власти, каждый из которых в пределах своей компетенции обязаны и должны обеспечивать правовой статус гражданина.

Граждане, в силу особенной организации государственной власти, наиболее часто взаимодействуют, а также общаются с представителями исполнительной власти, в компетенции которой сосредоточены основные финансовые, организационные, а также информационные ресурсы, особое место в системе исполнительной власти занимает полиция. Значение полиции в системе государственного управления, а также в жизнедеятельности общества очень велико. Полиция располагает достаточно серьезными полномочиями в деле противодействия преступности, а также административным правонарушениям. Полиция обладает всеми возможностями для того, что бы непосредственно обеспечить соблюдение прав граждан, кроме того, полиция обязана предпринимать должные меры для обеспечения личной и имущественной безопасности физических и юридических лиц. В отличие от других органов исполнительной власти, которые также осуществляют полицейскую деятельность, российская полиция обеспечивает права граждан посредством весьма специфических методов, а именно: административного надзора, прямого административного принуждения, а также иных материальных и процессуальных средств, которые реализуются в соответствующей форме. Принуждение полиции, а также иные методы, посредством которых обеспечиваются политические, экономические, личные, социальные, а также иные права граждан в сфере государственного управления, могут достигнуть своей цели только тогда, когда они основываются на предписаниях закона, кроме того, такое воздействие должно выдерживать необходимый ему материальный и процессуальный режим.

Принуждение, как средство обеспечения прав и законных интересов граждан играет, безусловно, важную роль в этом вопросе. Однако сотрудникам полиции в своей профессиональной деятельности нужно учитывать и другие средства воздействия на волю и сознание людей, а именно - использовать меры разъяснительного, информационного воздействия, насколько это возможно, вовлекать 
граждан в мероприятия по охране общественного порядка, особенно целесообразно проводить такую работу участковым уполномоченным полиции, а также сотрудникам патрульно-постовой службы. Нужно отметить, что ряд прав граждан в сфере обеспечения общественной безопасности просто не может быть реализован без предоставления государственных услуг органами внутренних дел, например, по лицензированию частной детективной и охранной деятельности, а также по контролю за ее осуществлением.

Необходимо подчеркнуть, что без полиции граждане не могут полноценно реализовать свои политические и социально-культурные права. Так, при проведении различных публичных, а именно политических или спортивно-зрелищных мероприятий, сотрудники полиции проводят работу по недопущению групповых (массовых) нарушений общественного порядка. Посредством технических и организационно-тактических приемов сотрудники полиции обеспечивают правопорядок и безопасность каждого отдельно взятого человека, присутствующего на соответствующем мероприятии. Нужно также сказать, что органы внутренних дел располагает весьма серьезными информационными ресурсами, которые используются в служебной деятельности полиции для выявления, раскрытия и расследования преступлений, установления личности тех лиц, которые могут быть причастны к их совершению. Без этого представить работу современной полиции просто нельзя. Однако есть и другой аспект использования информационных ресурсов органов внутренних дел - это предоставления гражданам важной для них информации и документов, в частности, справок об отсутствии судимости. Этот документ дает возможность гражданам реализовать свои права в сфере трудовой, например, педагогической деятельности, реализовать права в сфере усыновления (удочерения) детей, получить визу для въезда в другую страну или получить вид на жительство в другом государстве.
Помимо позитивных прав, полиция обеспечивает гражданам возможность реализовать их процессуальные права, которые им предоставляются как участникам производства по делам об административных правонарушениях. Особо следует сказать о необходимости обеспечения прав граждан при применении мер государственного принуждения.

Согласно Федеральному закону от 7 февраля 2011 г. «0 полиции» ${ }^{25}$, полиция защищает право каждого на свободу и личную неприкосновенность. До судебного решения в случаях, установленных законом, лицо не может быть подвергнуто задержанию на срок более 48 часов (ст. 14). 0 задержании лица составляется протокол, в котором указываются дата, время и место его составления, должность, фамилия и инициалы сотрудника полиции, составившего протокол, сведения о задержанном лице, дата, время, место, основания и мотивы задержания, а также факт уведомления близких родственников или близких лиц задержанного лица. Сотрудники полиции обязаны обеспечить возможность задержанному лицу в кратчайший срок, но не позднее трех часов с момента его задержания, если иное не установлено уголовно-процессуальным законодательством Российской Федерации, реализовать его право на один телефонный разговор в целях уведомления близких родственников или близких лиц о своем задержании и месте нахождения. Такое уведомление, по просьбе задержанного лица, может сделать сотрудник полиции.

В целях наиболее полного обеспечения прав граждан, представляется целесообразным закон «0 полиции» дополнить предписанием о том, что задержанный за административное правонарушение так же имеет право на один телефонный разговор в целях уведомления близких родственников или близких лиц о своем задержании и местонахождения. Как мы видим, из вышесказанного, органы внутренних дел в целом и полиция, в частности, обеспечивает различные права граждан, для этих целей используя весьма разносторонний инструментарий.

\section{Библиография:}

1. Арзамасов Ю.Г. Нормотворческая деятельность МВД России в механизме реализации прав человека и гражданина. - М., 2000.

2. Алехин А.П., Кармолицкий А.А., Козлов Ю.М. Административное право Российской Федерации. - М., 1997.

3. Буденко Н.И. Административно-правовое положение граждан в сфере общественного порядка: Дис. ... канд. юрид. наук. - М., 1986.

25 Собрание законодательства РФ. — 2011. — № 7. — Ст. 900. 
4. Бахрах Д.Н. Административное право России. - М., 2000.

5. Воеводин Л.Д. Юридический статус личности в России. - М., 1997.

6. Витрук Н.В. Общая теория правового положения личности. - М., 2008.

7. Соломатина Е.А. Правовое регулирование деятельности полиции в зарубежных странах // NB: Российское полицейское право. - 2013. - 3. - C. 104-118. DOI: 10.7256/2306-4218.2013.3.8916. URL: http://www.e-notabene.ru/pm/article_8916.html

8. Костенников М.В., Трофимов О.Е. Правовое регулирование транспортной безопасности и роль полиции в ее обеспечении // NB: Административное право и практика администрирования. - 2013. - 9. C. 18-52. DOI: 10.7256/2306-9945.2013.9.10134. URL: http://www.e-notabene.ru/al/article_10134.html

9. Куракин А.В. Социальная политика и российская полиция // NB: Российское полицейское право. 2013. - 3. - C. 1-23. DOI: 10.7256/2306-4218.2013.3.8914. URL: http://www.e-notabene.ru/pm/ article_8914.html

10. Куракин А.В. Компетенция полиции в сфере реализации законодательства об административных правонарушениях // NB: Административное право и практика администрирования. - 2013. - 4. C. 28-48. DOI: 10.7256/2306-9945.2013.4.8841. URL: http://www.e-notabene.ru/al/article_8841.html

11. Бочаров С. Н. К вопросу о взаимодействии органов внутренних дел и частных охранных организаций // Административное и муниципальное право. - 2012. - 12. - С. 61-63.

12. Трегубова Е.В. Административные запреты в сфере осуществления полицейской деятельности // NB: Российское полицейское право. - 2013. - 1. - C. 25-44. DOI: 10.7256/2306-4218.2013.1.718. URL: http://www.e-notabene.ru/pm/article_718.html

\section{References:}

1. Arzamasov Yu.G. Normotvorcheskaya deyatel'nost' MVD Rossii v mekhanizme realizatsii prav cheloveka i grazhdanina. - M., 2000.

2. Alekhin A.P., Karmolitskii A.A., Kozlov Yu.M. Administrativnoe pravo Rossiiskoi Federatsii. — M., 1997.

3. Budenko N.I. Administrativno-pravovoe polozhenie grazhdan v sfere obshchestvennogo poryadka: Dis. ... kand. yurid. nauk. - M., 1986.

4. Bakhrakh D.N. Administrativnoe pravo Rossii. - M., 2000.

5. Voevodin L.D. Yuridicheskii status lichnosti v Rossii. - M., 1997.

6. Vitruk N.V. Obshchaya teoriya pravovogo polozheniya lichnosti. — M., 2008.

7. Solomatina E.A. Pravovoe regulirovanie deyatel'nosti politsii v zarubezhnykh stranakh // NB: Rossiiskoe politseiskoe pravo. - 2013. - 3. - C. 104-118. DOI: 10.7256/2306-4218.2013.3.8916. URL: http://www.enotabene.ru/pm/article_8916.html

8. Kostennikov M.V., Trofimov O.E. Pravovoe regulirovanie transportnoi bezopasnosti i rol' politsii $\mathrm{v}$ ee obespechenii // NB: Administrativnoe pravo i praktika administrirovaniya. - 2013. - 9. - C. 18-52. DOI: 10.7256/2306-9945.2013.9.10134. URL: http://www.e-notabene.ru/al/article_10134.html

9. Kurakin A.V. Sotsial'naya politika i rossiiskaya politsiya // NB: Rossiiskoe politseiskoe pravo. — 2013. — 3. — C. 1-23. DOI: 10.7256/2306-4218.2013.3.8914. URL: http://www.e-notabene.ru/pm/article_8914.html

10. Kurakin A.V. Kompetentsiya politsii $\mathrm{v}$ sfere realizatsii zakonodatel'stva ob administrativnykh pravonarusheniyakh // NB: Administrativnoe pravo i praktika administrirovaniya. - 2013. - 4. - C. 28-48. DOI: 10.7256/2306-9945.2013.4.8841. URL: http://www.e-notabene.ru/al/article_8841.html

11. Bocharov S.N. K voprosu o vzaimodeistvii organov vnutrennikh del i chastnykh okhrannykh organizatsii // Administrativnoe i munitsipal'noe pravo. - 2012. - 12. - C. 61-63.

12. Tregubova E.V. Administrativnye zaprety v sfere osushchestvleniya politseiskoi deyatel'nosti // NB: Rossiiskoe politseiskoe pravo. - 2013. - 1. - C. 25-44. DOI: 10.7256/2306-4218.2013.1.718. URL: http://www.enotabene.ru/pm/article_718.html 